\title{
Some Novel Schiff Bases from Pyruvic Acid with Amines Containing N \& S Donor Atoms: Synthesis, Spectral Studies and X-Ray Crystal Structures
}

\author{
Abdul Azim Jambol'1, Malai Haniti Sheikh Abdul Hamid ${ }^{*}$, Aminul Huq Mirza1, \\ Md. Shafiqul Islam², Mohammad Rezaul Karim² \\ ${ }^{1}$ Chemical Sciences, Faculty of Science, Universiti Brunei Brunei Darussalam, Bandar Seri Begawan, Brunei Darussalam \\ ${ }^{2}$ Department of Chemistry, Tennessee State University, Nashville, USA \\ Email: ^haniti.hamid@ubd.edu.bn
}

How to cite this paper: Jambol, A.A., Hamid, M.H.S.A., Mirza, A.H., Islam, M.S. and Karim, M.R. (2017) Some Novel Schiff Bases from Pyruvic Acid with Amines Containing N \& S Donor Atoms: Synthesis, Spectral Studies and X-Ray Crystal Structures. International Journal of Organic Chemistry, 7, 42-56.

https://doi.org/10.4236/ijoc.2017.71005

Received: December 27, 2016

Accepted: March 4, 2017

Published: March 7, 2017

Copyright $\odot 2017$ by authors and Scientific Research Publishing Inc. This work is licensed under the Creative Commons Attribution International License (CC BY 4.0).

http://creativecommons.org/licenses/by/4.0/ (c) (i) Open Access

\begin{abstract}
Four Schiff bases, from pyruvic acid (1) with amines containing $\mathrm{N}$ and $\mathrm{S}$ donor atoms, thiocarbohydrazide (2, 61\%), 2-methyl-3-thiosemicarbazide (3, $26 \%), S$-benzyldithiocarbazate $(4,51 \%)$ and $S$ - $n$-octyldithiocarbazate $(5,63 \%)$ have been successfully synthesized. The conventional method was used and a series of novel linear and cyclic Schiff bases were obtained with or without catalyst. All the Schiff bases were fully characterized by CHN elemental analysis, FT-IR, ${ }^{1} \mathrm{H} \&{ }^{13} \mathrm{C}$ NMR, EI-MS and two of the Schiff bases were further characterized by X-ray crystallographic structure analysis. Compound 2 crystallizes in the triclinic space group $\mathrm{P}-1$ and unit cell dimensions are: $\mathrm{a}=$ 4.1777(8), $\mathrm{b}=$ 5.9538(11), $\mathrm{c}=13.458(3) \AA, \alpha=92.759(6), \beta=90.813(6), \gamma=$ $100.040(6)^{\circ}, R_{1}=0.0439$. Compound 3 crystallizes in the orthorhombic space group $\mathrm{P} \mathrm{n}$ a 2(1) and unit cell dimensions are: $\mathrm{a}=5.5992(2), \mathrm{b}=11.3962(5), \mathrm{c}$ $=10.6473(5), \alpha=92.759(6), \beta=90.813(6), \gamma=100.040(6)^{\circ}, \mathrm{R}_{1}=0.0285$. Compounds 2 and 3 were obtained as cyclic Schiff bases which are triazine derivatives.
\end{abstract}

\section{Keywords}

Pyruvic Acid Schiff Bases, Thiocarbohydrazide, $S$-Alkyldithiocarbazates, Thiosemicarbazide, Triazine, $\mathrm{N}$ and $\mathrm{S}$ Containing Amines

\section{Introduction}

In recent decades, much attention has been focused on Schiff bases derived from $S$-alkyl/aryl ester of dithiocarbazic acid such as $S$-benzyldithiocarbazate, $S$-me- 
thyldithiocarbazate and $S$-n-octyldithiocarbazate [1] [2] [3] [4] as well as thiocarbohydrazide [5] [6] [7] and substituted thiosemicarbazide [8]. These dithiocarbazates were condensed with carbonyl compounds such as pyruvic acid to synthesize several novel Schiff bases which could lead to many potential applications. This is because they contain mixed hard and soft donor atoms nitrogen, oxygen and sulfur which are ideal as chelating agents for metal ions. Most of the organic chelators are capable of exhibiting a wide range of biological potentials such as anticancer [1] [7] [8] [9] [10], antibacterial [5] [7] [11] [12], antifungal [5] [13]. They also have other applications as catalysts in reactions or as photoactive materials [14]. The terminal amino group in thiosemicarbazide and thiocarbohydrazide on the other hand, is highly nucleophilic toward C-eletrophiles because of the activating effect of its adjacent nitrogen which is susceptible to partake in different reactions such as amide formation and Schiff base formation [15] [16]. Due to this phenomenon, these amines namely thiosemicarbazide and thiocarbohydrazide have been reported to yield a series of five, six and seven membered heterocycles when treated with different compounds such as carboxylic acid or esters. Thiocarbohydrazide has a general tendency to form $\mathrm{N}$-amino compound in ring closure reaction such as condensation reaction with $\alpha$-ketocarboxylic acids to form triazines [15] [16]. Therefore, in view of their potential medical application and our continuing interest in the synthesis of new Schiff bases, we hereby report the preparation and characterization of new Schiff bases from pyruvic acid with $S$ - $n$-octyldithiocarbazate and $S$-benzyldithiocarbazate along with the preparation and characterization of the Schiff bases obtained from pyruvic acid with thiocarbohydrazide and 2-methyl-3-thiosemicarbazide together with their X-ray crystallographic structure analysis.

\section{General Method and Procedures}

\subsection{Materials and Methods}

\subsubsection{Materials}

All chemicals and solvents used were of analytical reagent grade and used without any further purification. Pyruvic acid and 2-methyl-thiosemicarbazide were purchased from the Aldrich Chemical Company, thiocarbohydrazide was purchased from Fluka and used without further purification. Both $S$-benzyldithiocarbazate and $S$ - $n$-octyldithiocarbazate were prepared following previously reported procedures [17] [18] [19] [20].

\subsubsection{Methods}

The IR spectra were recorded using ATR on Shimadzu FT-IR IR-Prestige21 in the range of $4000-400 \mathrm{~cm}^{-1}$. The EI mass spectra were recorded on an Agilent Mass Spectrometer 5975 C MSD (with direct probe). All the experiments were done at the Chemical Sciences, Faculty of Science, UBD. The NMR spectra were recorded in $\mathrm{CDCl}_{3}$ or $\mathrm{DMSO}_{-\mathrm{d} 6}$ as internal standard on a BrukerAvance, 400 MHz NMR Spectrometer carried out by the Nuclear Magnetic Resonance Laboratory, Department of Chemistry, National University of Singapore and some 
were done in $\mathrm{DMSO}_{-\mathrm{d} 6}$ by Tennessee State University, Michigan, USA. Elemental analysis for $\mathrm{C}, \mathrm{H}$ and $\mathrm{N}$ was done by the Elemental Analysis Laboratory, Department of Chemistry, National University of Singapore. The X-ray data were collected using a Bruker AXS D8 VENTURE Single Crystal X-ray Diffractometer at the X-ray Diffraction Laboratory, Department of Chemistry, National University of Singapore.

\subsection{Crystal Structure Determination and Refinement}

A single crystal of compound $\mathbf{2}$ and compound $\mathbf{3}$ were measured at low temperature $(\mathrm{T}=100 \mathrm{~K})$ on a four circles goniometer Kappa geometry Bruker AXS D8 Venture equipped with a Photon $100 \mathrm{CMOS}$ active pixel sensor detector using a Molybdenemonochromatized ( $\lambda=0.71073 \AA$ ) X-Ray radiation. Frames were integrated with the Bruker SAINT software package using a narrow-frame algorithm. Data were corrected for absorption effects using the multi-scan method implanted in the software (SADABS). Structure was solved using direct methods and subsequent differences Fourier maps, then refined by least squares procedures on weighted $F^{2}$ values using the SHELXL-version 2014/6 included in WinGx system programs for Windows. All non-hydrogen atoms were assigned anisotropic displacement parameters. Hydrogen atoms were located on difference Fourier maps then introduced as fixed contributors with an isotropic thermal parameters fixed at $20 \%$ higher than those carbons atoms they were attached, except for the hydrogen atom labelled $\mathrm{H} 1$ attached to the nitrogen atom N1 that was isotropically refined [21] [22] [23] [24] [25].

\subsection{General Procedure for Synthesis of Schiff Bases (2-5) from Pyruvic Acid (1)}

Schiff bases were synthesized from the condensation reaction of pyruvic acid with 2-methyl-3-thiosemicarbazide, thiocarbohydrazide, $S$-benzyldithiocarbazate and $S$-n-octyldithiocarbazate in absolute ethanol (but thiocarbohydrazide was dissolved in methanol) and refluxed for 1 - 2 hours. After cooling at room temperature overnight, the solid products obtained were filtered, washed with cold absolute ethanol and dried in the desiccator over anhydrous silica gel. The details of the syntheses of the Schiff bases are fully described in sections 2.4 - 2.7. The spectral data of characterization for all four synthesized Schiff bases are shown in Table 1.

\subsection{Synthesis of Schiff Base (2) from Pyruvic Acid (1)}

Pyruvic acid $(0.62 \mathrm{~g}, 7.00 \mathrm{mmol})$ and thiocarbohydrazide $(0.37 \mathrm{~g}, 3.50 \mathrm{mmol})$ were dissolved in $\mathrm{MeOH}(45 \mathrm{~mL})$ in a $100 \mathrm{~mL}$ round bottom flask. The reaction mixture was refluxed for 2 hours to give a pale yellow colour. The volume of the reaction mixture was reduced to half of its original volume and left to stand on the bench overnight. After 1 week, the pale yellow product obtained was filtered, washed with cold $\mathrm{MeOH}$ and dried in the vacuo over anhydrous silica gel. The product was recrystallized from abs.ethanol to afford 2. Yield: $61 \%$; m.pt: $182^{\circ} \mathrm{C}-183^{\circ} \mathrm{C}$. 
Table 1. Spectral data of the synthesized compounds.

\begin{tabular}{|c|c|}
\hline Compound & Spectral Data \\
\hline 2 & $\begin{array}{c}\mathrm{IR}, v\left(\mathrm{~cm}^{-1}\right): 3294,3208,3173(\mathrm{~N}-\mathrm{H}), 2909\left(\mathrm{CH}_{3}\right), 1659(\mathrm{C}=\mathrm{O}), 1519(\mathrm{C}=\mathrm{N}), 1215(\mathrm{C}=\mathrm{S}) \\
{ }^{1} \mathrm{H} \text { NMR }\left(\mathrm{CDCl}_{3}, 400 \mathrm{M} \mathrm{Hz}, \delta \mathrm{ppm}\right): \delta_{H}=10.3(1 \mathrm{H}, \mathrm{s},-\mathrm{NH}), 6.2\left(2 \mathrm{H}, \mathrm{s},-\mathrm{NH}_{2}\right), 2.3\left(3 \mathrm{H}, \mathrm{s},-\mathrm{CH}_{3}-\mathrm{C}\right) \\
{ }^{13} \mathrm{C} \text { NMR }(\mathrm{DMSO}-\mathrm{d} 6,100 \mathrm{M} \mathrm{Hz}, \delta \mathrm{ppm}): \delta_{C}=168.4(\mathrm{C}=\mathrm{S}), 148.8(\mathrm{C}=\mathrm{O}), 145.2(\mathrm{C}=\mathrm{N}), 16.5\left(\mathrm{CH}_{3}\right) \\
\text { Anal.calcd. for } \mathrm{C}_{4} \mathrm{H}_{6} \mathrm{~N}_{4} \mathrm{OS}: \mathrm{C} 30.37, \mathrm{H} 3.82, \mathrm{~N} 35.42 \text {; Found }(\%) \mathrm{C} 30.46, \mathrm{H} 3.77, \mathrm{~N} 35.43 ; \mathrm{MS} / \mathrm{EI} \\
\left.\mathrm{m} / \mathrm{z}(\mathrm{I}, \%) \text { for } \mathrm{C}_{4} \mathrm{H}_{6} \mathrm{~N}_{4} \mathrm{OS} \text { (m.w.: } 158.19 \mathrm{~g} / \mathrm{mol}\right):[\mathrm{M}]^{+\bullet} 158(100),\left[\mathrm{M}^{+} \cdot-\mathrm{CO}\right]^{+} 130(4),\left[\mathrm{M}^{+\bullet}-\mathrm{NCCH}_{3}\right]^{+} 89(1) \text {. }\end{array}$ \\
\hline 3 & 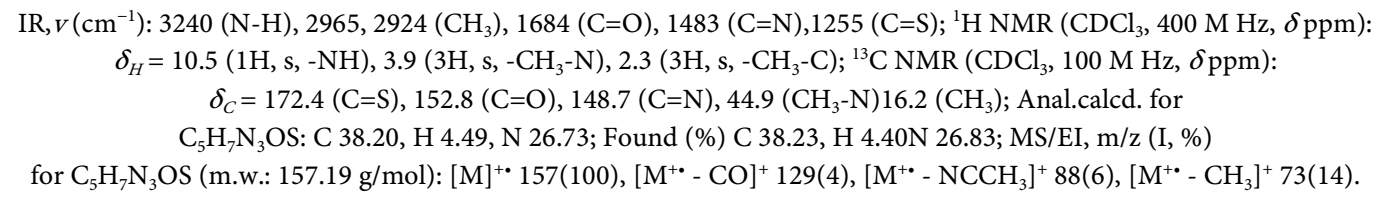 \\
\hline 4 & 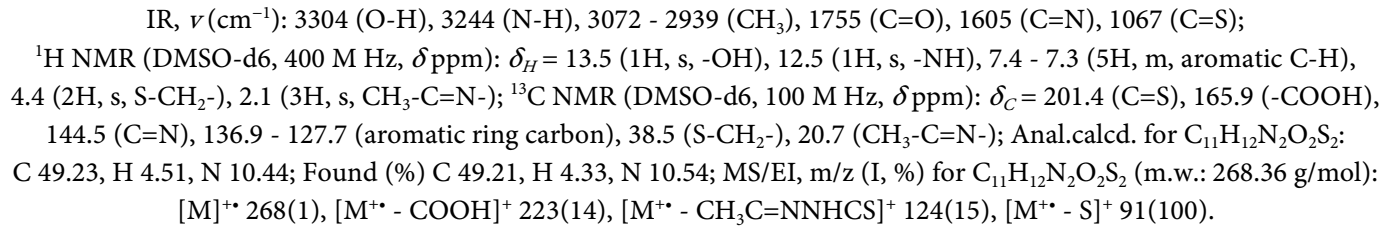 \\
\hline 5 & 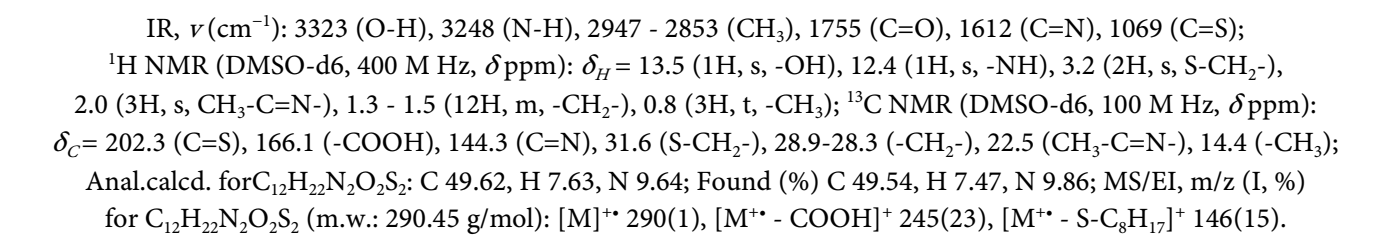 \\
\hline
\end{tabular}

\subsection{Synthesis of Schiff Base (3) from Pyruvic Acid (1)}

Pyruvic acid (0.44 g, $5.00 \mathrm{mmol})$ and 2-methyl-3-thiosemicarbazide (0.52 g, 5.00 $\mathrm{mmol})$ were dissolved in abs. EtOH $(30 \mathrm{~mL})$ and $4 \AA$ molecular sieves $(0.50 \mathrm{~g})$ were added and refluxed for 1 hour on a steam bath to give a yellow reaction mixture. The reaction mixture was then left to stand on the bench overnight. Yellow needle crystals obtained were filtered and washed with cold EtOH and dried in the desiccator over anhydrous silica gel to give 3 . The product was recrystallized from abs. EtOH to afford a crystalline product.Yield: 26\%; m.pt: $160^{\circ} \mathrm{C}-162^{\circ} \mathrm{C}$.

\subsection{Synthesis of Schiff Base (4) from Pyruvic Acid (1)}

Pyruvic acid (0.26 g, $3.00 \mathrm{mmol})$ and $S$-benzyldithiocarbazate $(0.59 \mathrm{~g}, 3.00$ $\mathrm{mmol})$ were dissolved in abs. EtOH $(15 \mathrm{~mL})$ in a round bottomed flask and 2-3 drops of glacial acetic acid added. The mixture was refluxed for 30 minutes to give a bright yellow colour. The reaction mixture was left to stand on the bench overnight. The yellow solids obtained were filtered, washed with cold EtOH and dried in a desiccator over anhydrous silica gel. Yield: $51 \%$; m.pt: $169^{\circ} \mathrm{C}-170^{\circ} \mathrm{C}$.

\subsection{Synthesis of Schiff Base (5) from Pyruvic Acid (1)}

Pyruvic acid $(0.26 \mathrm{~g}, 3.00 \mathrm{mmol})$ and $S$ - $n$-octyldithiocarbazate $(0.66 \mathrm{~g}, 3.00$ $\mathrm{mmol})$ were dissolved in abs. EtOH $(40 \mathrm{~mL})$ in a round bottomed flask and 2 - 3 drops of glacial acetic acid were added and refluxed for 2 hours to give a bright 
yellow reaction mixture. The mixture was then left to stand on the bench overnight. After 13 days, the yellow solids formed were filtered, washed with cold $\mathrm{EtOH}$ and dried in a desiccator over anhydrous silica gel. The product was recrystallized from acetonitrile to give yellow solids. Yield: $63 \%$; m.pt: $130^{\circ} \mathrm{C}$ $132^{\circ} \mathrm{C}$.

\section{Results and Discussion}

\subsection{Spectral Studies}

The synthetic pathways and physical properties of the four Schiff bases from pyruvic acid are shown in Scheme 1 and Table 2 respectively. The identification

Table 2. Physical properties of the Schiff bases.

\begin{tabular}{|c|c|c|c|c|c|c|}
\hline \multirow{2}{*}{ Compound } & \multirow{2}{*}{ Appearance } & \multirow{2}{*}{$\begin{array}{l}\text { Empirical } \\
\text { Formula }\end{array}$} & \multirow{2}{*}{$\begin{array}{l}\text { Molecular } \\
\text { weight }\end{array}$} & \multicolumn{3}{|c|}{ Elemental Analysis Found/Calculated. } \\
\hline & & & & $\% \mathrm{C}$ & $\% \mathrm{H}$ & $\% \mathrm{~N}$ \\
\hline 2 & $\begin{array}{l}\text { Pale yellow } \\
\text { crystals }\end{array}$ & $\mathrm{C}_{4} \mathrm{H}_{6} \mathrm{~N}_{4} \mathrm{OS}$ & 158.18 & $30.46(30.37)$ & $3.77(3.82)$ & $35.43(35.42)$ \\
\hline 3 & Yellow crystals & $\mathrm{C}_{5} \mathrm{H}_{7} \mathrm{~N}_{3} \mathrm{OS}$ & 157.19 & $38.23(38.20)$ & $4.40(4.49)$ & $26.83(26.73)$ \\
\hline 4 & Yellow solid & $\mathrm{C}_{11} \mathrm{H}_{12} \mathrm{~N}_{2} \mathrm{O}_{2} \mathrm{~S}_{2}$ & 268.36 & $49.25(49.23)$ & $4.35(4.51)$ & $10.56(10.44)$ \\
\hline 5 & Yellow solid & $\mathrm{C}_{12} \mathrm{H}_{22} \mathrm{~N}_{2} \mathrm{O}_{2} \mathrm{~S}_{2}$ & 290.45 & $49.54(49.62)$ & $7.47(7.63)$ & $9.86(9.64)$ \\
\hline
\end{tabular}<smiles>Cc1nn(C)c(=S)[nH]c1=O</smiles>

3

Yield $=26 \%$

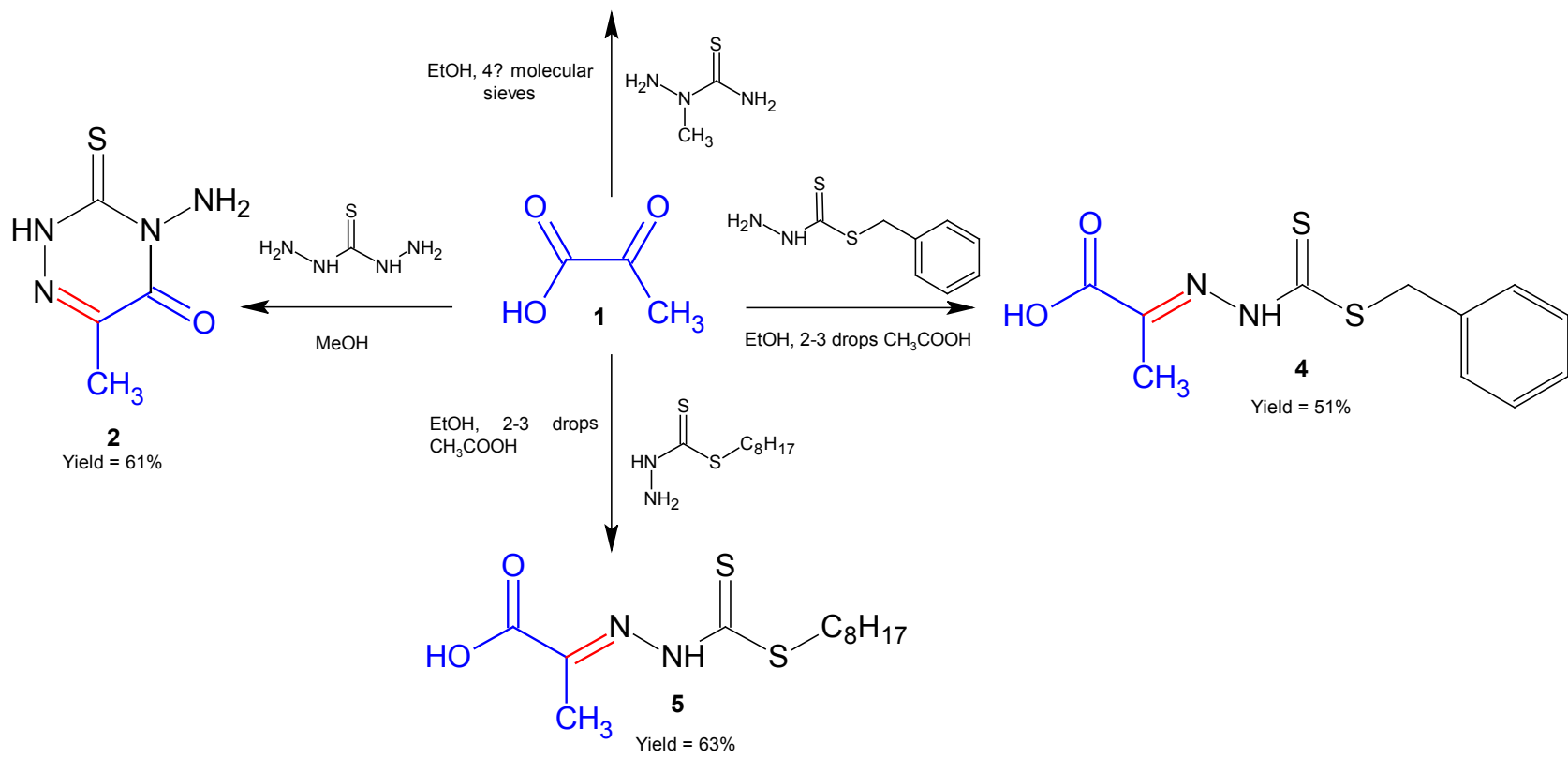

Scheme 1. The synthetic pathways of Schiff bases from compound 1 with different amines containing $\mathrm{N}$ and $\mathrm{S}$ donor atoms. 
of all the synthesized Schiff bases were confirmed by infrared, elemental analysis, ${ }^{1} \mathrm{H} \&{ }^{13} \mathrm{C}$ NMR, mass spectrometry and two Schiff bases were further analyzed by $\mathrm{X}$-ray crystallographic structure analysis. The results of elemental analysis for all compounds presented in Table 2 are in good agreement with the calculated values.

Schiff base 2 was synthesized from pyruvic acid and thiocarbohydrazide. This compound was first reported by Dornow, A. et al. [26] and the crystal and molecular structure of 2 was reported by Ghassemzadeh, M. et al. [27], who reported that compound 2 consists of planar C,N-heterocycles connected by hydrogen bridges $\left(Z=2, R_{1}=0.0441\right)$. The cyclic structure of compound 2 was obtained instead of a linear structure presumably due to several stages involved during the process of ring formation. It is probable that the first stage of the reaction involves the formation of imine from the condensation of the keto group and the primary amine of the thiocarbohydrazide (and not the carboxyl group of pyruvic acid). The next stage involves the attack of the amide nitrogen atom of thiocarbohydrazide on the electron deficient carbonyl carbon atom of carboxyl group of pyruvic acid moiety and followed by closure of the ring with loss of water to yield the target molecule as shown in Scheme 2 [15] [16] [28]. The process of cyclization of compound $\mathbf{3}$ is also similar to compound 2 except the amine involved in this process is 2 -methyl-3-thiosemicarbazide. Similarly, the infrared spectra of compounds $\mathbf{2}$ and $\mathbf{3}$ also have a missing $\mathrm{OH}$ stretching band confirming the cyclization process had taken place.

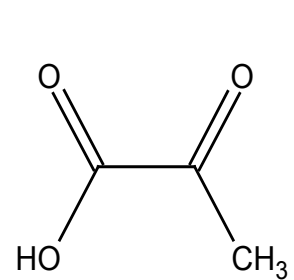

Pyruvic acid<smiles>NNC(=S)NN</smiles>

Thiocarbohydrazide<smiles>C/C(=N\NC(=S)NN)C(=O)O[13CH](O)O</smiles><smiles>CC(=O)[SH]=c1[nH]nc(C)c(=O)n1N</smiles>

Compound $2($ Yield $=61 \%)$

Scheme 2. The formation compound 2 and elimination of water molecule as a by-product. 


\subsubsection{Schiff Bases 2 and 3}

The amine NH stretching bands were recorded at $3294-3173 \mathrm{~cm}^{-1}$ and the azomethine $(\mathrm{C}=\mathrm{N})$ band was observed at $1519 \mathrm{~cm}^{-1}$. The $>\mathrm{CH}$ functional group can be found in the region of $2909 \mathrm{~cm}^{-1}$ and the band at $1659 \mathrm{~cm}^{-1}$ belongs to the amide $\mathrm{C}=\mathrm{O}$ functional group. The ${ }^{1} \mathrm{H}$ NMR spectrum of Schiff base 2 indicated that the most deshielded peak was at $10.3 \mathrm{ppm}$ singlet caused by a secondary amine $(>\mathrm{NH})$ then followed by a singlet peak of the primary amine $\left(\mathrm{NH}_{2}\right)$ at 6.2 ppm and $2.3 \mathrm{ppm}$ singlet peak of a methyl group $\left(\mathrm{CH}_{3}\right)$ respectively. The ${ }^{13} \mathrm{C}$ NMR spectrum of compound $\mathbf{2}$ is almost similar to compound $\mathbf{3}$ whereby the most deshielded peak was a thioamide $\mathrm{C}=\mathrm{S}$ at $168.4 \mathrm{ppm}$, amide $\mathrm{C}=\mathrm{O}$ at 148.8 ppm, azomethine $\mathrm{C}=\mathrm{N}$ at $145.2 \mathrm{ppm}$ and the methyl group at $16.5 \mathrm{ppm}$ respectively. The EI-MS spectrum of compound 2 showed that the molecular ion at $\mathrm{m} / \mathrm{z} 158\left(\mathrm{M}^{+\bullet}\right)$ as the base peak.

Compound 3, on the other hand is a cyclic Schiff base condensed from pyruvic acid and 2-methyl-3-thiosemicarbazide. This compound was first reported by Ruiz, J. et al. but the crystal structure has not been reported yet [29]. The cyclic structure was obtained instead of a linear structure also presumably due to the formation of imine from the condensation of the keto group and the primary amine of the 2-methyl-3-thiosemicarbazide in a similar mechanism as described for compound 2. The final step was the elimination of water molecule of carboxyl group moiety and the target molecule was achieved as shown in Scheme 3 [15] [16] [28].

The IR spectrum of compound 3 indicated that only one band of amine group at $3240 \mathrm{~cm}^{-1}$ was observed due to that the secondary amine $(>\mathrm{NH})$ present and

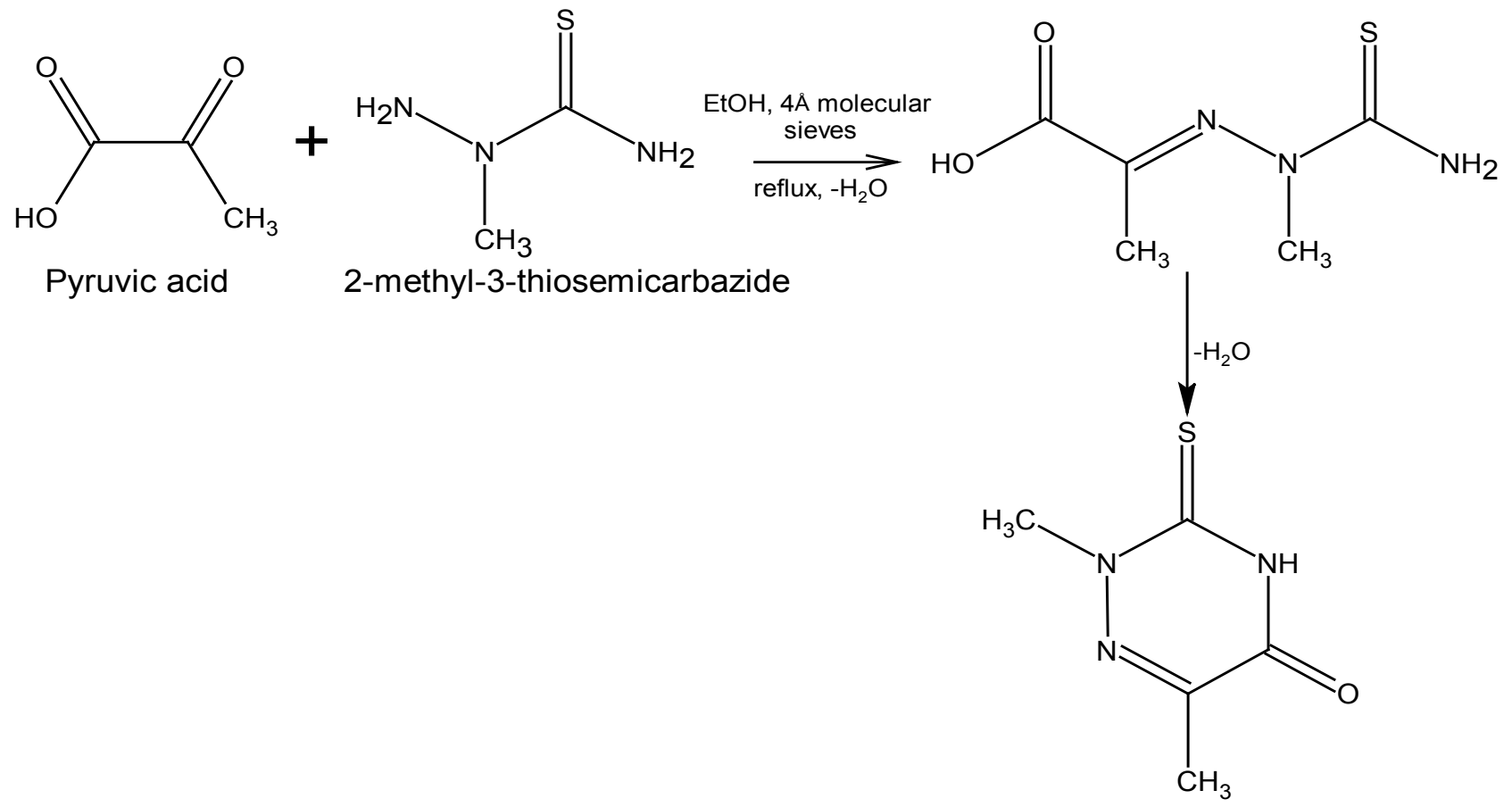

Compound 3 (Yield $=26 \%)$

Scheme 3. The formation of compound 3 and water as by-product. 
not the primary amine as observed at $1483 \mathrm{~cm}^{-1}$ due to the formation of azomethine $(\mathrm{C}=\mathrm{N})$. The $>\mathrm{CH}$ functional group can be found in the region of 2965 $2924 \mathrm{~cm}^{-1}$ and the band at $1684 \mathrm{~cm}^{-1}$ can be attributed to the amide $(\mathrm{C}=\mathrm{O})$ functional group. The ${ }^{1} \mathrm{H}$ NMR spectrum of Schiff base 3 showed a singlet peak at $10.5 \mathrm{ppm}$ as the most deshielded peak due to a secondary amine $(>\mathrm{NH})$, followed by a singlet peak 3.9 ppm belonging to the methyl group attached to a nitrogen atom and $2.3 \mathrm{ppm}$ singlet peak of the methyl group attached to a carbon atom. In the ${ }^{13} \mathrm{C}$ NMR spectrum, the chemical shift order can be arranged as from the most deshielded: $\mathrm{C}=\mathrm{S} 172.4 \mathrm{ppm},>\mathrm{C}=\mathrm{O} 152.8 \mathrm{ppm},>\mathrm{C}=\mathrm{N} 148.7 \mathrm{ppm}$ and methyl groups at $44.9 \mathrm{ppm}$ and $16.2 \mathrm{ppm}$ respectively. This is an unual case of a carbonyl $\mathrm{C}=\mathrm{O}$ having lower chemical shift than a thioamide $\mathrm{C}=\mathrm{S}$. This is because the carbonyl group in this compound is an amide $\mathrm{C}=\mathrm{O}$, and not a ketone or an aldehyde. An amide $\mathrm{C}=\mathrm{O}$ has lower chemical shift than the mentioned carbonyls but a thioamide $\mathrm{C}=\mathrm{S}$ has higher chemical shift than an amide [30] [31]. The EI-MS spectrum of compound 3 confirmed that the molecular ion appeared at $m / z 157\left(\mathrm{M}^{+\bullet}\right)$ as a base peak.

\subsubsection{Schiff Bases 4 and 5}

Compound 4 is a linear Schiff base andwas synthesized from the condensation of pyruvic acid and $S$-benzyldithiocarbazate. The IR spectrum showed that $\mathrm{OH}$ band was present at $3304 \mathrm{~cm}^{-1}$, a secondary $\mathrm{NH}$ band at $3244 \mathrm{~cm}^{-1}$, $=\mathrm{CH}$ band at the region of $3072 \mathrm{~cm}^{-1}$ to confirm the presence of a benzyl ring. On the other hand, the acid $(\mathrm{C}=\mathrm{O})$ functional group was observed at $1755 \mathrm{~cm}^{-1}$ and the azomethine $(\mathrm{C}=\mathrm{N})$ at $1605 \mathrm{~cm}^{-1}$. ${ }^{1} \mathrm{H}$ NMR spectrum of Schiff base 4 indicated that the most deshielded peak was observed at 13.5 ppm singlet caused by an $-\mathrm{OH}$ group of carboxylic acid (-COOH) then followed by $12.5 \mathrm{ppm}$ singlet of $-\mathrm{NH}$ group, then multiplet peaks of aromatic proton $=\mathrm{CH}$ from $7.4-7.3 \mathrm{ppm}$ and a singlet peak of $\mathrm{S}-\mathrm{CH}_{2}$ - was observed at $4.4 \mathrm{ppm}$ then followed the least deshielded peak of $\mathrm{CH}_{3}-\mathrm{C}=\mathrm{N}$ - at $2.1 \mathrm{ppm}$. The ${ }^{13} \mathrm{C}$ NMR spectrum of compound 4 showed that the most deshielded peak was a thione $\mathrm{C}=\mathrm{S}$ at $201.4 \mathrm{ppm}$, followed by $165.9 \mathrm{ppm}$ of carboxylic acid - $\mathrm{COOH}, 144.5 \mathrm{ppm}$ of azomethine $\mathrm{C}=\mathrm{N}$, aromatic carbon at 136.9-127.7 ppm, then at $38.5 \mathrm{ppm}$ was assigned to $\mathrm{S}-\mathrm{CH}_{2}$ - and lastly the least deshielded peak at 20.7 ppm was assigned to $\mathrm{CH}_{3}-\mathrm{C}=\mathrm{N}-$. The EI-MS spectrum of compound 4 confirmed that the molecular ion appeared at $\mathrm{m} / z 268\left(\mathrm{M}^{+\bullet}\right)$ and thetropylium ion was observed as a base peak at $\mathrm{m} / z 91$.

For compound 5, the $\mathrm{OH}$ functional group was found at $3323 \mathrm{~cm}^{-1}$, the secondary $\mathrm{NH}$ functional group was observed at $3248 \mathrm{~cm}^{-1}$, the $\mathrm{CH}$ stretching bands were found in the region of $2947-2853 \mathrm{~cm}^{-1}$ for the long chain of alkyl group in the compound, whilst the acid $(\mathrm{C}=\mathrm{O})$ stretching band was recorded at $1755 \mathrm{~cm}^{-1}$ and azomethine $(\mathrm{C}=\mathrm{N})$ band was found at $1612 \mathrm{~cm}^{-1} \cdot{ }^{1} \mathrm{H}$ NMR spectrum of Schiff base 5 reported that the most deshielded peak was found at 13.5 ppm singlet caused by an $-\mathrm{OH}$ group of carboxylic acid $(-\mathrm{COOH})$, then 12.4 ppm of singlet peak of $-\mathrm{NH}$ group, followed by a singlet peak of $\mathrm{S}-\mathrm{CH}_{2}$ - at 3.2 ppm and followed by a methyl group of $\mathrm{CH}_{3}-\mathrm{C}=\mathrm{N}$ - at $2.0 \mathrm{ppm}$, then a long chain of methylene $-\mathrm{CH}_{2}$ - was observed at $1.5-1.3 \mathrm{ppm}$ and lastly the least deshielded 
peak at $0.8 \mathrm{ppm}$ was assigned to the terminal $-\mathrm{CH}_{3}$ of the octyl chain. The ${ }^{13} \mathrm{C}$ NMR spectrum of compound 5 reported that the most deshielded peak was observed at $202.3 \mathrm{ppm}$ of thione $\mathrm{C}=\mathrm{S}$, at $166.1 \mathrm{ppm}$ was caused by a $\mathrm{C}=\mathrm{O}$ of carboxylic group (-COOH), $144.3 \mathrm{ppm}$ azomethine $\mathrm{C}=\mathrm{N}, 31.6 \mathrm{ppm} \mathrm{S}-\mathrm{CH}_{2}$, long chain of methylene $-\mathrm{CH}_{2}$ - of octyl group was observed at 28.9-28.3 ppm, methyl group of $\mathrm{CH}_{3}-\mathrm{C}=\mathrm{N}$ - at $22.5 \mathrm{ppm}$ and lastly terminal $-\mathrm{CH}_{3}$ at $14.4 \mathrm{ppm}$ was reported as the most shielded. The molecular ion peak of the compound was observed at $m / z 290\left(\mathrm{M}^{+}\right)$in the EI-MS spectrum.

Both Schiff bases 4 and 5 have the thioamide functional group (-NH-C(=S)) in their backbones and therefore, thione-thioltautomerism is expected. The absence of any $v S-H$ band at $c a .2570 \mathrm{~cm}^{-1}$ in their IR spectra is also strong evidence that they remain in their thionetautomeric forms and also no - $\mathrm{SH}$ proton was observed in the ${ }^{1} \mathrm{H}$ NMR. This proved that these compounds exist as thione form in $\mathrm{DMSO}_{-\mathrm{d} 6}$ as shown in Scheme 4 [32].

\subsection{X-Ray Crystallography}

The X-ray crystallographic images of compounds $\mathbf{2}$ and $\mathbf{3}$ are depicted in Figure 1 and Figure 2, and the selected bond lengths and bond angles of compounds 2 and 3 are recorded in Table 3 and Table 4 respectively. The precise crystal data for compounds 2 and 3 are reported in Table 5.

Table 3. Selected bond lengths $(\AA)$ and bond angles $\left({ }^{\circ}\right)$ for compound 2 .

\begin{tabular}{cccc}
\hline Bond & Bond Length $(\AA)$ & Bond & Bond Angle $\left(^{\circ}\right)$ \\
\hline $\mathrm{C}(1)-\mathrm{S}(1)$ & $1.655(2)$ & $\mathrm{N}(1)-\mathrm{C}(1)-\mathrm{N}(3)$ & $113.63(18)$ \\
$\mathrm{C}(1)-\mathrm{N}(3)$ & $1.386(2)$ & $\mathrm{N}(2)-\mathrm{C}(2)-\mathrm{C}(3)$ & $122.43(18)$ \\
$\mathrm{N}(1)-\mathrm{N}(2)$ & $1.352(2)$ & $\mathrm{N}(1)-\mathrm{C}(1)-\mathrm{S}(1)$ & $122.65(15)$ \\
$\mathrm{C}(3)-\mathrm{N}(3)$ & $1.373(2)$ & $\mathrm{N}(2)-\mathrm{C}(2)-\mathrm{C}(4)$ & $119.6(2)$ \\
$\mathrm{C}(2)-\mathrm{C}(3)$ & $1.448(3)$ & $\mathrm{N}(3)-\mathrm{C}(1)-\mathrm{S}(1)$ & $123.73(16)$ \\
$\mathrm{C}(2)-\mathrm{N}(2)$ & $1.298(3)$ & $\mathrm{O}(1)-\mathrm{C}(3)-\mathrm{N}(3)$ & $120.6(2)$ \\
$\mathrm{C}(3)-\mathrm{O}(1)$ & $1.231(2)$ & $\mathrm{O}(1)-\mathrm{C}(3)-\mathrm{C}(2)$ & $123.62(18)$ \\
\hline
\end{tabular}

Table 4. Selected bond lengths $(\AA)$ and bond angles $\left({ }^{\circ}\right)$ for compound 3.

\begin{tabular}{cccc}
\hline Bond & Bond Length $(\AA)$ & Bond & Bond Angle $\left(^{\circ}\right)$ \\
\hline $\mathrm{S}(1)-\mathrm{C}(1)$ & $1.666(2)$ & $\mathrm{C}(1)-\mathrm{N}(3)-\mathrm{N}(2)$ & $124.44(17)$ \\
$\mathrm{N}(3)-\mathrm{C}(1)$ & $1.353(2)$ & $\mathrm{N}(2)-\mathrm{N}(3)-\mathrm{C}(4)$ & $113.52(15)$ \\
$\mathrm{N}(2)-\mathrm{N}(3)$ & $1.377(2)$ & $\mathrm{C}(1)-\mathrm{N}(1)-\mathrm{C}(2)$ & $126.13(16)$ \\
$\mathrm{N}(3)-\mathrm{C}(4)$ & $1.461(3)$ & $\mathrm{N}(3)-\mathrm{C}(1)-\mathrm{S}(1)$ & $124.09(16)$ \\
$\mathrm{C}(3)-\mathrm{C}(5)$ & $1.492(3)$ & $\mathrm{N}(1)-\mathrm{C}(1)-\mathrm{S}(1)$ & $121.34(14)$ \\
$\mathrm{N}(2)-\mathrm{C}(3)$ & $1.289(3)$ & $\mathrm{O}(1)-\mathrm{C}(2)-\mathrm{N}(1)$ & $121.92(19)$ \\
$\mathrm{O}(1)-\mathrm{C}(2)$ & $1.223(3)$ & $\mathrm{O}(1)-\mathrm{C}(2)-\mathrm{C}(3)$ & $124.9(2)$ \\
\hline
\end{tabular}


<smiles>[R]SC(=S)NN=C(C)C(=O)O</smiles>

Thione form<smiles>[R]S/C(S)=N/N=C(\C)C(=O)O</smiles>

Thiol form

$$
\mathrm{R}=\mathrm{C}_{7} \mathrm{H}_{7}, \mathrm{C}_{8} \mathrm{H}_{17}
$$

Scheme 4. The thione and thiol tautomeric forms of the Schiff bases 4 and 5 .

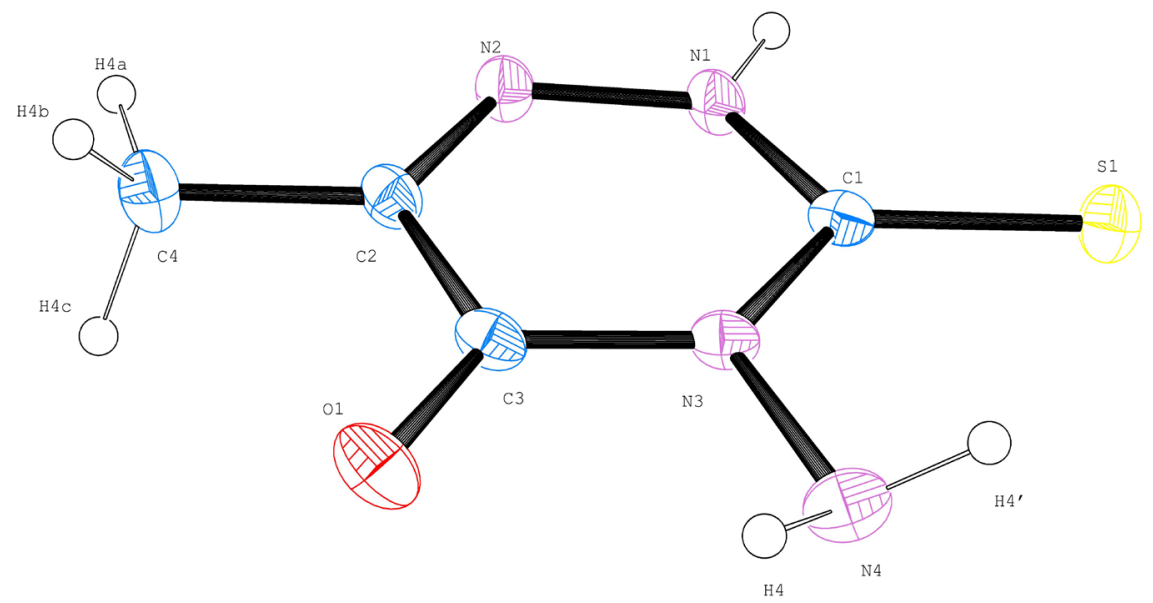

Figure 1. A general view and atom labelling of X-ray structure of compound 2.

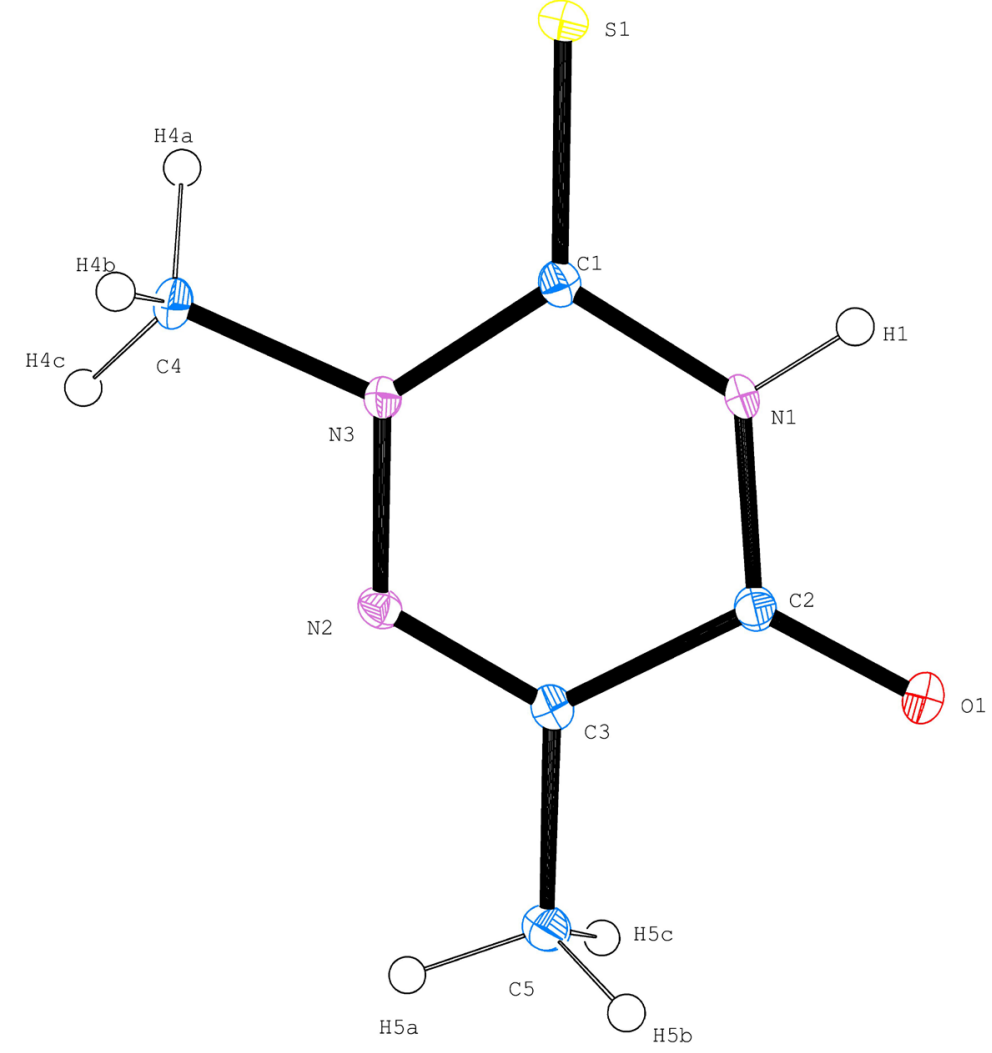

Figure 2. A general view and atom labelling of X-ray structure of compound 3. 
Table 5. Precise crystal data for compounds 2 and 3.

\begin{tabular}{|c|c|c|}
\hline Compound & 2 & 3 \\
\hline Empirical formula & $\mathrm{C}_{4} \mathrm{H}_{6} \mathrm{~N}_{4} \mathrm{OS}$ & $\mathrm{C}_{5} \mathrm{H}_{7} \mathrm{~N}_{3} \mathrm{OS}$ \\
\hline Formula weight & 158.19 & 157.20 \\
\hline Temperature & $200(2) \mathrm{K}$ & $100(2) \mathrm{K}$ \\
\hline Wavelength & $0.71073 \AA$ & $0.71073 \AA$ \\
\hline Crystal system & Triclinic & Orthorhombic \\
\hline Space group & $\mathrm{P}-1$ & $\mathrm{P}$ n a $2(1)$ \\
\hline \multirow[t]{6}{*}{ Unit cell dimensions } & $\mathrm{a}=4.1777(8) \AA$ & $a=5.5992(2) \AA$ \\
\hline & $\mathrm{b}=5.9538(11) \AA$ & $\mathrm{b}=11.3962(5) \AA$ \\
\hline & $c=13.458(3) \AA$ & $c=10.6473(5) \AA$ \\
\hline & $\alpha=92.759(6)^{\circ}$ & $\alpha=92.759(6)^{\circ}$ \\
\hline & $\beta=90.813(6)^{\circ}$ & $\beta=90.813(6)^{\circ}$ \\
\hline & $\gamma=100.040(6)^{\circ}$ & $\gamma=100.040(6)^{\circ}$ \\
\hline Volume & $329.15(11) \AA^{3}$ & $679.40(5) \AA^{3}$ \\
\hline $\mathrm{Z}$ & 2 & 4 \\
\hline Density (calculated) & $1.596 \mathrm{Mg} / \mathrm{m}^{3}$ & $1.537 \mathrm{Mg} / \mathrm{m}^{3}$ \\
\hline Absorption coefficient & $0.421 \mathrm{~mm}^{-1}$ & $0.403 \mathrm{~mm}^{-1}$ \\
\hline $\mathrm{F}(000)$ & 164 & 328 \\
\hline Crystal size & $0.218 \times 0.214 \times 0.075 \mathrm{~mm}^{3}$ & $0.218 \times 0.174 \times 0.085 \mathrm{~mm}^{3}$ \\
\hline Theta range for data collection & 3.032 to $28.277^{\circ}$ & 2.618 to $30.513^{\circ}$ \\
\hline Index ranges & $-5<=\mathrm{h}<=5,-6<=\mathrm{k}<=7,-17<=1<=17$ & $-8<=\mathrm{h}<=6,-16<=\mathrm{k}<=16,-11<=1<=15$ \\
\hline Reflections collected & 4777 & 7595 \\
\hline Independent reflections & $1561[\mathrm{R}(\mathrm{int})=0.0410]$ & $1757[\mathrm{R}(\mathrm{int})=0.0319]$ \\
\hline Completeness to theta $=25.242^{\circ}$ & $95.0 \%$ & $100.0 \%$ \\
\hline Refinement method & Full-matrix least-squares on $\mathrm{F}^{2}$ & Full-matrix least-squares on $\mathrm{F}^{2}$ \\
\hline Data/restraints/parameters & $1561 / 0 / 102$ & $1757 / 1 / 95$ \\
\hline Goodness-of-fit on $\mathrm{F}^{2}$ & 1.017 & 1.062 \\
\hline Final $\mathrm{R}$ indices $[\mathrm{I}>2 \operatorname{sigma}(\mathrm{I})]$ & $\mathrm{R} 1=0.0439, \mathrm{wR} 2=0.0917$ & $\mathrm{R} 1=0.0285, \mathrm{wR} 2=0.0676$ \\
\hline $\mathrm{R}$ indices (all data) & $\mathrm{R} 1=0.0774, \mathrm{wR} 2=0.1019$ & $\mathrm{R} 1=0.0325, \mathrm{wR} 2=0.0697$ \\
\hline Largest diff. peak and hole & 0.323 and -0.236 e. $\AA^{-3}$ & 0.341 and -0.195 e. $\AA^{-3}$ \\
\hline
\end{tabular}

Compound 2 was condensed from pyruvic acid with thiocarbohydrazide in methanol and the product was recrystalized in absolute ethanol to afford pale yellow crystals and further analyzed by X-ray crystallographic structure analysis. Compound 2 crystallizes in the triclinic space group $\mathrm{P}-1, \mathrm{R}_{1}=0.0439$ and the six-membered ring framework is depicted in Figure 1. The delocalization of $\pi$-electrons is obvious from the bond lengths viz. C1-N3 as 1.386(2) $\AA$ which is similar to the literature value of 1.381(3) $\AA$ and C2-N2 as 1.298 (3) $\AA$, also similar to the reported value of 1.294(4) $\AA$ [27]. In addition, the bond lengths for S1- 
C1 is $1.655(2) \AA$ and O1-C3 is 1.231 (2) $\AA$ that shows a high double bond character similar to the literature value respectively at 1.654(3) $\AA$ and 1.236(3) $\AA$ [27].

The condensation process between pyruvic acid and 2-methyl-3-thiosemicarbazide in absolute ethanol produced Schiff base 3 . The product was recrystalized in absolute ethanol to afford yellow rod-like crystals and was further investigated by single $\mathrm{X}$-ray diffraction. Compound $\mathbf{3}$ crystallizes in the orthorhombic space group $P$ n a 2(1), $R_{1}=0.0285$ and the six-membered ring framework is depicted in Figure 2. The delocalization of $\pi$-electrons is obvious from the bond lengths viz. C1-N3 as 1.353(2) $\AA$ and C3-N2 as 1.289 (3) $\AA$ which are very similar to the values for compound 2. In addition, the bond lengths for $\mathrm{S} 1-\mathrm{C} 1$ is $1.666(2) \AA$ which is also similar with compound 2 but the O1-C2 is 1.223 (3) $\AA$ which was found to be slightly lower than the value for compound 2 .

\section{Conclusion}

Four Schiff bases of pyruvic acid of which two are new compounds were successfully synthesized and characterized by a variety of physico-chemical techniques. From the results obtained, the condensation of pyruvic acid with $S$-alkyldithiocarbazate reacted to give compounds $\mathbf{4}$ and $\mathbf{5}$ as linear Schiff bases, whilst compounds $\mathbf{2}$ and $\mathbf{3}$ were found to be cyclic Schiff bases obtained from the condensation of pyruvic acid with thiocarbohydrazide and 2-methyl-3-thiosemicarbazide respectively. X-ray crystallographic structure analysis of compounds 2 and 3 further confirmed the cyclic nature of the Schiff bases and the structural aspects were discussed.

\section{Acknowledgements}

We are grateful to the Chemical Sciences, Faculty of Science, Universiti Brunei Darussalam for the necessary support in carrying out the research work. We also thank the National University of Singapore and the Department of Chemistry, Tennessee State University for running the spectral and analytical data.

\section{References}

[1] Mirza, A.H., Hamid, M.H.S.A., Aripin, S., Karim, M.R., Arifuzzaman, M., Ali, M.A. and Bernhardt, P.V. (2014) Synthesis, Spectroscopy and X-Ray Crystal Structures of Some Zinc(II) and Cadmium(II) Complexes of the 2-Pyridinecarboxaldehyde Schiff Bases of S-Methyl- and S-Benzyldithiocarbazates. Polyhedron, 74, 16-23. https://doi.org/10.1016/j.poly.2014.02.016

[2] Ali, M.A., Mirza, A.H., Ting, W.Y., Hamid, M.H.S.A., Bernhardt, P.V. and Butcher, R.J. (2012) Mixed-Ligand Nickel(II) and Copper(II) Complexes of Tridentate ONS and NNS Ligands Derived from S-Alkyldithiocarbazates with the Saccharinate Ion as a Co-Ligand. Polyhedron, 48, 167-173. https://doi.org/10.1016/j.poly.2012.08.069

[3] Asri, I., Hamid, M.H.S.A., Mirza, A.H., Ali, M.A. and Karim, M.R. (2014) Octyl (2E)-2-[2-(diphenylphosphanyl)benzylidene]hydrazinecarbodithioate. Acta Crystallographica Section E, 70, 633-634. https://doi.org/10.1107/S1600536814008459

[4] Begum, M.S., Zangrando, E., Sheikh, M.C., Miyataked, R. and Hossain, M.M. (2015) 
Crystal Structure of S-Octyl (E)-3-(4-methoxybenzylidene)dithiocarbazate. Acta Crystallographica, E71, 265-266. https://doi.org/10.1107/s205698901500568x

[5] Kumar, G. and Rajeev Johari, S.D. (2012) Synthesis and Spectral Characterization of Schiff Base Cr(III), Mn(III), and Fe(III) Novel Macrocyclic Complexes Derived from Thiocarbohydrazide and Dicarbonyl Compound. E-Journal of Chemistry, 9, 2255-2260. https://doi.org/10.1155/2012/956812

[6] Kumar, G., Kumar, A., Shishodia, N., Garg, Y.P. and Yadav, B.P. (2011) Synthesis, Spectral Characterization and Antimicrobial Evaluation of Schiff Base Cu(II), Ni(II) and Co(II) Novel Macrocyclic Complexes. E-Journal of Chemistry, 8, 1872-1880. https://doi.org/10.1155/2011/497279

[7] Sathisha, M.P., Shetti, U.N., Revankar, V.K. and Pai, K.S.R. (2008) Synthesis and Antitumor Studies on Novel $\mathrm{Co}(\mathrm{II}), \mathrm{Ni}(\mathrm{II})$ and $\mathrm{Cu}(\mathrm{II})$ Metal Complexes of bis(3-acetylcoumarin)thiocarbohydrazone. European Journal of Medicinal Chemistry, 43, 2338-2346. https://doi.org/10.1016/j.ejmech.2007.10.003

[8] Belicchi Ferrari, M., Bisceglie, F., Pelosi, G., Tarasconi, P., Albertini, R. and Pinelli, S. (2001) New Methyl Pyruvate Thiosemicarbazones and Their Copper and Zinc Complexes: Synthesis, Characterization, X-Ray Structures and Biological Activity. Journal of Inorganic Biochemistry, 87, 137-147. https://doi.org/10.1016/S0162-0134(01)00321-X

[9] Pathan, A. and Gudasi, K. (2013) Transition Metal Complexes of Novel Ethyl Pyruvate Hydrazones as Potential Antitumor Agents: Synthesis and Physicochemical Properties, DNA Interactions and Antiproliferative Activity. Medicinal Chemistry Research, 22, 1504-1516. https://doi.org/10.1007/s00044-012-0111-1

[10] Hamid, M.H.S., Said, A.N.A., Mirza, A.H., Karim, M.R., Arifuzzaman, M., Ali, M.A. and Bernhardt, P.V. (2016) Synthesis, Structures and Spectroscopic Properties of Some Tin (IV) Complexes of the 2-Acetylpyrazine Schiff Bases of S-Methyl-and S-Benzyldithiocarbazates. Inorganica Chimica Acta, 453, 742-750. https://doi.org/10.1016/j.ica.2016.09.038

[11] Ameram, N. and Othman, U. (2013) Synthesis and Characterization of Co(Ii), $\mathrm{Cu}(\mathrm{Ii}), \mathrm{Cd}(\mathrm{Ii}), \mathrm{Zn}(\mathrm{Ii})$ and $\mathrm{Ni}(\mathrm{Ii})$ Complexes of Schiff Base Ligand Derived from S-Benzyldithiocarbazate (Sbdtc) and Acetophenone with Their Biological Activity Studies. IOSR Journal of Engineering, 3, 38-50. https://doi.org/10.9790/3021-03853850

[12] Alsughayer, A., Elassar, A., Mustafa, S. and Sagheer, F. (2011) Synthesis, Structure Analysis and Antibacterial Activity of New Potent Sulfonamide Derivatives. Journal of Biomaterials and Nanobiotechnology, 2, 143-148.

https://doi.org/10.4236/jbnb.2011.22018

[13] Ahmed, M.F.A. and Mahammadyunus, V. (2014) Microwave Synthesis and Antimicrobial Activity of Some Copper (II), Cobalt (II), Nickel (II) and Chromium (III) Complexes with Schiff Base 2, 6-Pyridinedicarboxaldehyde-thiosemicarbazone. Oriental Journal of Chemistry, 30, 111-117. https://doi.org/10.13005/ojc/300114

[14] Ali, O.A., El-Medani, S.M., Ahmed, D.A. and Nassar, D.A. (2015) Synthesis, Characterization, Fluorescence and Catalytic Activity of Some New Complexes of Unsymmetrical Schiff Base of 2-Pyridinecarboxaldehyde with 2, 6-Diaminopyridine. Spectrochimica Acta Part A: Molecular and Biomolecular Spectroscopy, 144, 99106. https://doi.org/10.1016/j.saa.2015.02.078

[15] Kurzer, F. and Wilkinson, M. (1970) Chemistry of Carbohydrazide and Thiocarbohydrazide. Chemical Reviews, 70, 111-149. https://doi.org/10.1021/cr60263a004

[16] Tehrani, K.H.M.E., Mashayekhi, V., Azerang, P., Minaei, S., Sardari, S. and Kobarfard, F. (2015) Synthesis and Antimycobacterialactivity of Some Triazolederiva- 
tives-New Route to Functionalized Triazolopyridazines. Iranian Journal of Pharmaceutical Research, 14, 59.

[17] Bähr, G. and Schleitzer, G. (1955) Über emprotide Schwermetall-Innerkomplexe der $\alpha$-Diketondi-thiosemicarbazone (Thia zone) IV. Untersuchungenzur Konstitution. Komplexe von Thiazon-Analogen Zeitschrift Für Anorganische Und Allgemeine Chemie, 280, 161. https://doi.org/10.1002/zaac.19552800402

[18] Das, M. and Livingstone, S.E. (1976) Metal Chelates of Dithiocarbazic Acid and Its Derivatives. IX. Metal Chelates of Ten New Schiff Bases Derived from S-Methyldithiocarbazate. Inorganica Chimica Acta, 19, 5. https://doi.org/10.1016/S0020-1693(00)91065-X

[19] Ali, M.A. and Tarafder, M.T.H. (1977) Metal Complexes of Sulphur and Nitrogen-Containing Ligands: Complexes of S-Benzyldithiocarbazate and a Schiff Base Formed by Its Condensation with Pyridine-2-Carboxaldehyde. Journal of Inorganic and Nuclear Chemistry, 39, 1785. https://doi.org/10.1016/0022-1902(77)80202-9

[20] Krautil, P. and Robson, R. (1980) Complexes of Binucleating Ligands. XIII. Soluble Complexes of a Ligand with a Bridging Thiophenoxide Component and Peripheral N-Octyl Substituents. Journal of Coordination Chemistry, 10, 7-12. https://doi.org/10.1080/00958978008079844

[21] Saint Program Included in the Package Software: APEX v2014.11.0.

[22] Sadabs, W.N. and Stuart, D. (1983) An Empirical Method for Correcting Diffractometer Data for Absorption Effects. Acta Crystallographica Section A, 39, 158-166. https://doi.org/10.1107/s0108767383000252

[23] Sheldrick, G.M. (2015) SHELXT-Integrated Space-Group and Crystal-Structure Determination. Acta Crystallographica Section A, A71, 3-8. https://doi.org/10.1107/S2053273314026370

[24] Sheldrick, G.M. (2008) SHELXTL. Acta Crystallographica Section A, 64, 112-122. https://doi.org/10.1107/S0108767307043930

[25] Farrugia, L.J. (1999) WinGX Suite for Small-Molecule Single-Crystal Crystallography. Journal of Applied Crystallography, 32, 837-838. https://doi.org/10.1107/S0021889899006020

[26] Dornow, A., Menzel, H. and Marx, P. (1964) Synthesenstickstoffhaltiger Heterocyclen, XXVII. Über 1.2. 4-Triazine, I Darstellungeinigerneuer s-Triazolo [3.2-c]-astriazine. Chemische Berichte, 97, 2173-2178. https://doi.org/10.1002/cber.19640970811

[27] Ghassemzadeh, M., Aghapoor, K., Heravi, M.M. and Neumüller, B. (1998) Synthesis and Crystal Structure of a New Sulfur-Palladium-Nitrogen Complex. Zeitschriftfüranorganische und allgemeine Chemie, 624, 1969-1972.

https://doi.org/10.1002/(SICI)1521-3749(1998120)624:12<1969::AID-ZAAC1969>3. $\underline{0 . \mathrm{CO} ; 2-3}$

[28] Aly, A.A., Brown, A.B., El-Emary, T.I., Ewas, A.M.M. and Ramadane, M. (2009) Hydrazinecarbothioamide Group in the Synthesis of heterocycles. Arkivoc, 1, 150197.

[29] Ruiz, J., Florenciano, F., López, G., Chaloner, P.A. and Hitchcock, P.B. (1998) Reactivity of $[\mathrm{NBu} 4] 2[\{(\mathrm{C} 6 \mathrm{X} 5) 2 \mathrm{M}(\mu-\mathrm{OH})\} 2](\mathrm{X}=\mathrm{F}$ or $\mathrm{Cl} ; \mathrm{M}=\mathrm{Pd}$ or Pt $)$ towards Heterocyclic Thiones: Crystal Structure of $[\mathrm{NBu} 4] 2[\{(\mathrm{C} 6 \mathrm{~F} \mathrm{5}) 2 \mathrm{Pd}(\mu-\nu 2-\mathrm{LL}$ ') $\}$ 2] (LL' = Methylimidazole-2-thiolate). Inorganica Chimica Acta, 281, 165-173. https://doi.org/10.1016/S0020-1693(98)00164-9

[30] Crews, P., Rodriguez, J. and Jaspars, M. (1998) Organic Structure Analysis. Oxford University Press, Oxford, 58-95. 
[31] Kolanos, R., Wysocka, W. and Brukwicki, T. (2003) A Comparative Study of NMR Chemical Shifts of Sparteinethiolactams and Lactams. Tetrahedron, 59, 5531-5537. https://doi.org/10.1016/S0040-4020(03)00813-5

[32] Ali, M.A., Mirza, A.H., Butcher, R.J. and Crouse, K.A. (2006) The Preparation, Characterization and Biological Activity of Palladium (II) and Platinum (II) Complexes of Tridentate NNS Ligands Derived from S-Methyl- and S-Benzyldithiocarbazates and the X-Ray Crystal Structure of the [Pd (mpasme) Cl] Complex. Transition Metal Chemistry, 31, 79-87. https://doi.org/10.1007/s11243-005-6305-3

\section{Appendix A: Supplementary Data}

CCDC No: 1,523,333 and 1,523,329 contain the supplementary crystallographic data for compounds 2 and 3 respectively. These data can be obtained free of charge via http://www.ccdc.cam.ac.uk/conts/retrieving.html, or from the Cambridge Crystallographic Data Centre, 12 Union Road, Cambridge CB2 1EZ, UK; fax: (+44)-1223-336-033; or e-mail: deposit@ccdc.cam.ac.uk.

Submit or recommend next manuscript to SCIRP and we will provide best service for you:

Accepting pre-submission inquiries through Email, Facebook, LinkedIn, Twitter, etc. A wide selection of journals (inclusive of 9 subjects, more than 200 journals)

Providing 24-hour high-quality service

User-friendly online submission system

Fair and swift peer-review system

Efficient typesetting and proofreading procedure

Display of the result of downloads and visits, as well as the number of cited articles

Maximum dissemination of your research work

Submit your manuscript at: http://papersubmission.scirp.org/

Or contact ijoc@scirp.org 